\title{
Domicile of Children: the New Law in Scotland
}

\section{Sirko Harder}
A. INTRODUCTION
B. THE NEW TEST OF CLOSEST CONNECTION
(1) Parents with same domicile
(2) Parents with different domiciles
(3) One or both parents dead
C. CHANGES TO DOMICILE OF ORIGIN AND DOMICILE OF CHOICE
(1) The traditional role of domicile of origin
(2) The background to section 22
(3) Four approaches to section 22
(4) Replacing the revival rule with the continuance rule
D. TRANSITIONAL PROVISION
E. CONCLUSION

\section{A. INTRODUCTION}

One of the objectives of the Family Law (Scotland) Act 2006, which came into force on 4 May 2006, ${ }^{1}$ is to abolish the status of illegitimacy in Scots law. ${ }^{2}$ In consequence, section 22 of the Act introduces a rule of domicile of children that no longer differentiates according to the marital status of the child's parents.

Domicile is still an important connecting factor in Scots private international law, for the civil status or "personal law" of a person is in general governed by the law of the country in which the person is domiciled. For instance, intestate

- Teaching Assistant in Law, University of Aberdeen. The author would like to thank Professor Peter McEleavy, Professor Chris Clarkson, and an anonymous referee for helpful comments on an earlier draft of this article.

1 Family Law (Scotland) Act 2006 (Commencement, Transitional Provisions and Savings) Order 2006, SSI 2006/212, art. 2.

2 To this end, s 21 of the Act amends s 1(1) of the Law Reform (Parent and Child) (Scotland) Act 1986.

3 This term is used, for instance, by A E Anton and P R Beaumont, Private International Law: A treatise from the standpoint of Scots law, $2^{\text {md }}$ edn (1990) $121 \mathrm{ff} ; \mathrm{P}$ M North and J J Fawcett, Cheshire and North's Private International Law, $13^{\text {th }}$ edn (1999) $134 \mathrm{ff}$. 
succession to moveables ${ }^{4}$ and the essential validity of testamentary dispositions of moveables 5 are governed by the law of the deceased's last domicile. The 2006 Act reaffirms the relevancy of domicile for the essential validity of a marriage, ${ }^{6}$ for the rights of spouses in each other's moveable property, ${ }^{7}$ and for questions of legitimacy and legitimation. ${ }^{\text {s }}$

The common law knows three types of domicile: domicile of origin, which the law assigns to every person at birth; domicile of choice, which can be both acquired and abandoned; and derivative domicile (or domicile of dependence) for persons who lack the capacity to choose their domicile themselves. The group of legally dependent persons includes children under the age of sixteen. ${ }^{9}$

In relation to the domicile of origin and the derivative domicile of children the common law differentiated according to the marital status of the child's parents. Legitimate children acquired at birth and subsequently followed their father's domicile whereas illegitimate children acquired and followed their mother's domicile. ${ }^{10}$ The domicile of the mother was further relevant for legitimate children whose father was dead and in general ${ }^{11}$ for legitimate children whose parents were divorced or separated.

The domicile of children is now governed by section 22 of the 2006 Act, which reads:

\section{Domicile of persons under 16}

(1) Subsection (2) applies where -

(a) the parents of a child are domiciled in the same country as each other; and

(b) the child has a home with a parent or a home (or homes) with both of them.

(2) The child shall be domicilcd in the same country as the child's parents.

(3) Where subsection (2) does not apply, the child shall be domiciled in the country with which the child has for the time being the closest connection.

(4) In this section, "child" means a person under 16 years of age.

Lashley $v$ Hog (1804) 4 Paton 581; Ommanney v Bingham (1796) 3 Paton 448; Boe v Anderson (1862) 24 D 732.

6 Family Law (Scotland) Act $2006 \mathrm{~s} 38$.

72006 Act $s 39$.

82006 Act s 41 . In relation to Scottish domiciliaries questions of legitimacy and legitimation will no longer arise as the status of illegitimacy is now abolished in Scots law.

9 The age limit of 16 years for all children was fixed by the Age of Legal Capacity (Scotland) Act 1991 s 7 (a provision repealed by the new Act). The previous law differentiated between pupils (girls under 12 and boys under 14) and minors and perhaps also between forisfamiliated and unforisfamiliated minors: Anton \& Beaumont, Private International Law 133-134.

10 "It is a settled principle that no man shall be without a domicil, and to secure this result the law attributes to every individual as soon as he is born the domicil of the father if the child be legitimate, or the domicil of the mother if illegitimate": $U d n y v U d n y$ (1869) 7 M (HL) 89 at 99 per Lord Westbury. The cases of foundlings, putative marriages, legitimation and adoption are discussed by Anton \& Beaumont, Private International Law 130-131.

11. For details see the Domicile and Matrimonial Proceedings Act $1973 \mathrm{~s} 4$. This provision is repealed for Scotland by the Family Law (Scotland) Act 2006 Sch 3. 
The effect of this rather intricate provision is that the domicile of a child is now in general the country with which the child is for the time being most closely connected. No longer does domicile depend on the marital status of the child's parents; no longer does it invariably follow that of the child's father or mother. However, where both parents are domiciled in the same country and the child has a home with at least one of them, the child shares the parents' domicile whether or not the test of closest connection would come to the same result.

It is clear that section 22 replaces the common law rules on the derivative domicile of children with a new test of closest connection. It is also clear that section 22 does not affect the common law rules on the acquisition of domicile of choice. What is unclear, however, is the extent to which section 22 alters the common law rules on domicile of origin and on the abandonment of a domicile of choice.

\section{B. THE NEW TEST OF CLOSEST CONNECTION}

By introducing a test of closest connection for the domicile of children the 2006 Act implements a recommendation made by the Law Commission for England and Wales and the Scottish Law Commission in their joint report on domicile of $1987,{ }^{12}$ reaffirmed by the Scottish Law Commission in its report on Family Law of $1992 .^{13}$ The 1987 report rejected the idea of replacing domicile as the determinant for status with either habitual residence or nationality. Habitual residence was considered too fluctuating a link between a person and a country to determine status, ${ }^{14}$ and nationality was considered too abstract a link for that purpose. ${ }^{15}$ In the case of children, the 1987 report rejected the idea of treating them like adults and making their domicile dependent on intention, since children, even where capable of forming the requisite intention, were under the control of an adult and thus not free in choosing where to live and for how long. ${ }^{16}$ For these reasons, the 1987 report subscribed to the test of treating a child as domiciled in the country with which the child was for the time being ${ }^{17}$ most closely connected.

12 Law Commission and Scottish Law Commission, Report on Private International Law: The Law of Domicile (Law Com No 168, Scot Law Com No 107, 1987) (henceforth Law Commissions, Report on Domicile). The Report was rejected by the UK Government in 1996: see Law Commission, Thirtieth Annual Report (Law Com No 239, 1996) para 1.15 n 24.

13 Scottish Law Commission, Report on Family Law (Scot Law Com No 135, 1992), paras 17.12 and 17.13 (henceforth Scottish Law Commission, Report on Family Law).

14 Law Commissions, Report on Domicile paras 3.5-3.8, 4.11.

15 Law Commissions, Report on Domicile paras 3.9-3.11.

16 Law Commissions, Report on Domicile para 4.10.

17 The phrase "for the time being" was said to indicate that the court has to find the closest connection as at the time for which the domicile needs to be determined. It was not intended to prevent the court from considering any previous event in the child's life: see Law Commissions, Report on Domicile para 4.18. 
It was thought that this test would allow the courts ${ }^{18}$

to reach the most appropriate conclusion taking into account all the circumstances of the case including, for example, the intentions of the child, if any, and of his parents or of those who have control over him; his and his parents' nationality; where he is or was in fact resident at the time in question; his family background and his education.

A further attraction of a closest connection test is that, in the case of a child who lives with neither parent, it provides a certain amount of built-in protection against a third party attempting to manipulate the child's domicile for some improper purpose.

Like the 1987 report, the Act does not seek to give guidance as to how closeness of connection is to be determined. This is to be welcomed. A court should be free to consider all the circumstances of the case when determining the domicile of a child. As the report pointed out, the mention of specific factors in the legislation could lead the courts to confining their attention to those factors. ${ }^{19}$

\section{(1) Parents with same domicile}

The Act does, however, contain a special provision for one situation. As already mentioned, it is provided in section 22 that where a child's parents are domiciled in the same country as each other and the child has a home with a parent or a home (or homes) with both of them, the child is domiciled in the same country as the parents. The Bill as introduced into the Scottish Parliament gave this rule in the form of a rebuttable presumption of closest connection, ${ }^{20}$ following a recommendation by the Law Commissions. ${ }^{21}$ It was one of six presumptions, all of which were later replaced by subsections (1) and (2) of section 22 . The replacement, it was explained, was simpler in application while still achieving the same policy objective as before. ${ }^{22}$

In the bulk of cases a child has indeed the closest connection with the country of the parents' domicile, especially where the child's home is in that country. But other situations are conceivable. Suppose the parents have the same country of origin (country $\mathrm{X}$ ), from which they have moved to country $\mathrm{Y}$ where they intend to live for a number of years until they move finally to country $Z$. They have no intention ever to return to $X$ and have cut all ties to $X$. Their child is born in $Y$, grows up in $Y$, socialises with the people of $Y$ and speaks their language. The child has never been to $\mathrm{X}$ nor has any contact with people living in $\mathrm{X}$. Yet the Act prescribes the

18 Law Commissions, Report on Domicile paras 4.12 and 4.13.

19 Law Commissions, Report on Domicile para 4.18.

20 Family Law (Scotland) Bill (as introduced) s 16(3)(a).

21 Law Commissions, Report on Domicile para 4.15; Scottish Law Commission, Report on Family Law para 17.13.

22 Statement by Hugh Henry, Deputy Minister for Justice: see Official Report, 9 November 2005, col 2261 (Justice 1 Committee). 
child to be domiciled in X. However, this and other situations where the inflexible rule in section 22(1) and (2) may seem inappropriate are rare indeed; and even on those rare occasions, it has the advantage that all family members share the same domicile.

In refraining from defining when a child has a "home", the Act follows the Law Commissions' lead. The word "home", said the 1987 report, sufficiently conveys "the combined ideas of physical presence and emotional link". ${ }^{23}$ Indeed, existing legislation already uses the concept of "home" without defining it, ${ }^{24}$ and this does not seem to have produced difficulties. The report took the view that a child has a "home" with the parent(s) not only when they live together day to day, but also where there are temporary separations on a regular basis, such as where the child attends a boarding school or is in hospital (even directly after birth) or where the parent works abroad. ${ }^{25}$ This accords with the definition of a child's "home" in the Children Act $1975 .{ }^{26}$ But the 1987 report went further and suggested that a child's "home" with the parent(s) may persist even where the child lives for a while with foster parents or in care. ${ }^{27}$ Whether this view will be adopted in practice remains to be seen.

\section{(2) Parents with different domiciles}

Adopting a recommendation by the Law Commissions, ${ }^{28}$ the Bill as introduced into the Scottish Parliament provided that where a child has a home with one parent only and the parents are not domiciled in the same country, it is presumed that the child is most closely connected with the country in which the parent with whom the child has a home is domiciled.$^{29}$ As already mentioned, this presumption was dropped for the sake of simplifying the application of what is now section 22 ; and indeed it seems preferable to determine the country of closest connection without the constraints of a presumption which is unnecessary in some cases and inappropriate in others. The presumption is unnecessary where the parent with whom the child has a home is domiciled in the country where the home is located,

23 Law Commissions, Report on Domicile para 4.20.

24 For instance Domicile and Matrimonial Proceedings Act $1973 \mathrm{~s} \mathrm{4;} \mathrm{Adoption} \mathrm{(Scotland)} \mathrm{Act} 1978 \mathrm{ss} 13$, 19, 20, 27, 28; Family Law (Scotland) Act 1985 s 1.3; Child Support Act 1991 ss 3, 42.

25 Law Commissions, Report on Domicile para 4.19.

26 Section 87(3). This reads: "In this Act, unless the context othenvise requires, references to the person with whom a child has his home refer to the person who, disregarding absence of the child at a hospital or boarding school and any other temporary absence, has actual custody of the child." The Children Act 1975 has been repealed for England and Wales but is still in force in Scotland.

27 Law Commissions, Report on Domicile para 4.20.

28 Law Commissions, Report on Domicile para 4.16; Scottish Law Commission, Report on Family Law para 17.13.

29 Family Law (Scotland) Bill (as introduced) s 16(3)(b). 
because there will rarely be doubt that the child has the closest connection with that country. And the presumption is inappropriate where the parent with whom the child has a home is not so domiciled, ${ }^{30}$ because this presumes the child to be most closely connected with the domicile of the parent rather than the country where the child lives. The child may have no connections to the country of the parent's domicile and the parent may intend never to return there.

The test of closest connection is also directly applicable where the child's parents have a different domicile and the child shares a home with both. This situation may arise where the parents have different intentions as to the permanence of their stay in the country where the joint home is located, or where their domicile of origin is in different countries and they now live temporarily in a third country. In order to create certainty in this situation, the consultation document leading up to the 1987 report proposed that the child share the mother's domicile. ${ }^{31}$ To noone's surprise, this arbitrary rule received a cold welcome from the commentators and was dropped in the 1987 report. $^{32}$ It was not revived either in the 1992 report or in the 2006 Act itself. Indeed, giving priority to the domicile of one parent would introduce through the backdoor the very inequality that the Act seeks to abolish.

\section{(3) One or both parents dead}

The Bill as introduced into Parliament contained as many as four presumptions for the domicile of a child with one or both parents dead. ${ }^{33}$ In the case of the death of a parent with whom the child had lived (the other parent being still alive), it was presumed that the child had the closest connection with the country of domicile of that parent or, if the child now lived with the other parent, of that parent. ${ }^{34}$ In the case of the death of both parents, the Bill provided for the persistence of the domicile which the child previously had in accordance with the presumptions discussed earlier.

The abandonment of these presumptions is welcome. A presumption that a child shares the domicile of the only living parent produces the same problems as the presumption, discussed earlier, that a child shares the domicile of the only parent with whom the child has a home where both parents are alive. And a presumption that the domicile a parent had at the time of death continues for

30 I.e. because that country is not the parent's domicile of origin and the parent intends to stay in that country only temporarily.

31 Law Commission and Scottish Law Commission, Private International Law: The Law of Domicile (Law Com WP No 88, Scot Law Com CM No 63, 1985) paras 4.6-4.9.

32 Law Commissions, Report on Domicile para 4.17.

33 Family Law (Scotland) Bill (as introduced) s 16(3)(c)-(f).

34 This largely followed the Domicile and Matrimonial Proceedings Act 1973 s 4(3). 
the child is inappropriate considering that the child may since have been lawfully brought to another jurisdiction by a guardian or foster parents. Indeed, the idea of making any presumptions for the domicile of orphans or children not living with their parents was already rejected in the consultation document leading to the 1987 report $^{35}$ and was not even found worthy of discussion in the report itself.

\section{CHANGES TO DOMICILE OF ORIGIN AND DOMICILE OF CHOICE}

While it is clear that the common law rules on the derivative domicile of children are completely replaced with the new test of closest connection, it is less certain whether and how the Act affects the common law rules on the domicile of origin and the abandonment of a domicile of choice.

\section{(1) The traditional role of domicile of origin}

At common law the domicile of origin is relevant where the status of a person has to be determined for the time of that person's birth; and if this were its only role nobody would doubt that domicile of origin too is now to be determined under the test of closest connection set out in section 22. For it would make no sense to have two different domicile regimes for the time of birth and the time immediately afterwards. But to determine the status of a person at the time of birth is not the only role the domicile of origin plays in the common law of Scotland and England. Under the traditional rules, a person can abandon a domicile of choice without simultaneously acquiring a new one. Since nobody can ever be without domicile, the person's domicile of origin then revives. ${ }^{36}$ For this reason, the domicile of origin remains relevant to the determination of a person's status up until that person's death. Indeed, disputes over succession often necessitate a determination of domicile as at the date of death. In that case, the deceased's domicile has to be traced from birth to death, with the possibility of the domicile of origin reviving even shortly before the death. ${ }^{37}$

35 Law Commission and Scottish Law Commission, Private International Law: The Law of Domicile (Law Com WP No 88, Scot Law Com CM No 63, 1985) paras 4.11 and 4.12.

36 The leading case is $U d n y v U d n y$ (1869) $7 \mathrm{M}(\mathrm{HL})$ S9. The revival rule was further applied in Amott $v$ Arnott's Trustees (1884) 22 SLR I, and Ross v Ross 1926 SLT 689 at 706 per Lord Ashmore. For English law see, for instance, Harrison v Harrison [1953] I WLR 865; Tee v Tee [1974] I WLR 213.

37 Earlier cases suggested that it was more difficult to change from the domicile of origin to a domicile of choice than from one domicile of choice to another. But this rule seems to have vanished from both Scots and English law: Law Commissions, Report on Domicile para 2.8. Should this rule still exist, it would belong to the rules on the acquisition of a domicile of choice and would not be affected by the 2006 Act. 


\section{(2) The background to section 22}

In considering the meaning of section 22 it is helpful to begin with some background. In their 1987 report the Law Commissions recommended an overhaul of the law of domicile as a whole, including the replacement of the revival rule ${ }^{38}$ with what may be called a "continuance rule", that is, a rule that a domicile of choice should persist until a new domicile of choice has been established. ${ }^{39}$ Having thus confined the role of domicile of origin to the determination of a person's domicile at the time of birth, the report went on to replace both the domicile of origin so confined and the derivative domicile of children with an independent domicile of children governed by a test of closest connection. As a result, the domicile of origin as a separate type of domicile with a separate set of rules was to "disappear from the laws of the United Kingdom". "With hindsight it is unfortunate that the 1987 report failed to emphasise that the domicile of origin can only be integrated into the concept of a domicile of children if the revival rule is abolished. For if the revival rule is retained, then so is domicile of origin as a separate type of domicile. If the domicile of origin may revive in a person's adult life, it cannot be integrated into a concept of a domicile of children. Consequently, the decision in the 1987 report to recommend abolition of the revival rule influenced the drafting of the provision introducing the test of closest connection. ${ }^{41}$

The Scottish Law Commission's 1992 report concerned family law, not the law of domicile. Since, however, the report recommended the abolition of the status of illegitimacy, it had to address the law on domicile insofar as this was necessary to achieve that aim. Approving the joint report of 1987 , the 1992 report said: ${ }^{4 ?}$

In the context of the abolition of the status of illegitimacy in Scots law it is clearly essential that the existing law on the domicile of children be changed. We therefore suggest that, if the joint report on domicile has not been implemented by the time this report is implemented, the Scottish law on the domicile of children should be changed in the way recommended in the joint report.

The 1992 report went on to copy from the 1987 report the rules on the domicile of children (the test of closest connection supplemented by two presumptions), adding that "It should be made clear that a person's domicile of origin is the first domicile which he or she has under the above rules." 43 The purpose of this last statement might simply be to clarify that the test of closest connection governs

38 I.e. the rule that the domicile of origin revives if a domicile of choice is abandoned without a replacenent.

39 Law Commissions, Report on Domicile paras 5.23-5.25.

40 Law Commissions, Report on Domicile para 4.24.

41 Law Commissions, Report on Domicile Appendix A, Draft Domicile Bill, Schedule para 1.

42 Scottish Law Commission, Report on Family Law para 17.13.

43 Scottish Law Commission, Report on Family Law para 17.13. 
the domicile of children not only for the time between birth and the age of sixteen but also for the time of birth itself. But the statement might also mean that the Scottish Law Commission took for granted the survival of the domicile of origin as a separate type of domicile including its ability to revive in a person's adult life. The latter meaning, however, seems unlikely if only because the relevant provision in the Commission's draft Bill ${ }^{44}$ says nothing as to the domicile of origin or the revival rule and bears a heading ("Domicile of Children") which would not be very accurate if the revival rule were being retained.

When the 2006 Act was drafted on the basis of the 1992 report, it seems to have been overlooked that the provision on the domicile of children recommended in that report had been copied from the 1987 report where it had been complemented by a provision replacing the revival rule with the continuance rule, and that the provision or at least its heading would have to be redrafted were the revival rule to be retained. The explanatory notes to what is now section 22 state simply that the provision eradicates the distinction between legitimate and illegitimate children in relation to domicile: "There will therefore no longer be a link between a child's domicile and that of his or her parents' marital status in relation to both the domicile of origin and the dependent domicile." ${ }^{, 45}$ Again, the reference to the domicile of origin might mean that a persistence of the revival rule was assumed but this would not sit happily with the heading of section 22 itself or with the omission of any mention that the test of closest connection might affect adults too through the revival of a domicile of origin governed by this test.

\section{(3) Four approaches to section 22}

In applying section 22 to domicile of origin, four approaches are theoretically possible. The first is to take both section 22 and its explanatory notes at their word and to apply section 22 to all types of domicile that children can have (but only to the domicile of children). This would mean that the domicile of a person from birth until the age of sixteen is governed by the new test of closest connection, supplemented by the specific rule in section 22(1) and (2). Thereafter domicile of origin would be determined by the common law rules with its distinction between legitimate and illegitimate children. The problem with this approach is that a person's domicile at birth could then be different from that person's domicile of origin for the purpose of filling a domicile gap in the person's adult life.

The second approach is to disregard the reference to the domicile of origin in the explanatory notes and to replace the common law rules with the rules in section

44 Scottish Law Commission, Report on Family Law Appendix A, Draft Family Law (Scotland) Bill cl $45(1)-(3)$.

45 Revised Explanatory Notes for Family Law (Scotland) Bill (as amended at Stage 2) para 36. 
22 only in relation to the derivative domicile of children but not in relation to the domicile of origin. This would ensure that a person has the same domicile of origin from birth to death. But it would mean that the domicile of origin remains subject to the common law distinction between legitimate and illegitimate children, the very distinction that the Act seeks to abolish. It would also mean that a person's domicile at birth could be different from the domicile immediately after birth, for while the former would be the domicile of the person's father or mother at that time, the latter would be governed by the test of closest connection.

The third approach is to replace the common law rules with the rules in section 22 in relation to both the domicile of origin and the derivative domicile of children. In that case the test of closest connection would govern a person's domicile at the time of birth, from birth until aged sixteen, and again whenever an adult abandons a domicile of choice without immediately acquiring a new one. This approach would avoid the obvious absurdities of the first two approaches but would not sit happily with the fact that section 22 defines the domicile for "persons under 16 " and thus discloses no intention of defining domicile after that age. ${ }^{46}$

The fourth and final approach is to replace the revival rule with the continuance rule, and to apply section 22 both to domicile at birth and to domicile from birth until aged $16 .{ }^{47}$ Since the domicile at birth could no longer revive at a later date, the domicile of origin as a separate type of domicile would disappear from Scots law. An abandonment of the revival rule would avoid the absurdities created by the first two approaches, and would render wholly accurate the reference in section 22 to persons under sixteen. Moreover, there are strong policy arguments for replacing the revival rule with the continuance rule.

\section{(4) Replacing the revival rule with the continuance rule}

The revival rule was developed in the nineteenth century with respect to those who settled or worked in the British colonies but with the intention of returning. ${ }^{45}$ Where these people ceased to have a permanent home it was indeed appropriate to determine their status in accordance with the law of their native country. As Faville J of the Supreme Court of Iowa said in Re Jones' Estate: ${ }^{49}$

Men left their native land knowing that they would be gone for long periods of time, and that means of communication with their home land were infrequent, difficult, and slow. The traditions of their native country were strong with these men. In the event

46 Apart, of course, from a domicile based on closest connection persisting after the age of 16 in the absence of a new domicile of choice.

47 As recommended by the Law Commissions' 1987 report: see C.(2) above.

48 A comparison with "elephants who allegedly return to their birthplace to die" is made by $\mathrm{C} M \mathrm{~V}$ Clarkson and J Hill, Jaffey on the Conflict of Laws, $2^{\text {md }}$ edn (2002) 30.

49 (192.1) 192 lowa 78 at 83 ; 182 NW 227 at 229-230. 
of death, while absent, they desired that their property should descend in accordance with the laws of the land of their birth. Many such men were adventurers who had the purpose and intent to eventually return to the land of their nativity. There was a large degree of patriotic sentiment connected with the first announcement of the rules of law in the matter of the estates of such men.

In the modern world, where people are much more ready to cut all ties to their country of birth, it is no longer justified to resort to the domicile of origin to fill a gap between two domiciles of choice. Rather, the status of a person in such a gap should be determined in accordance with the law of the country which was most recently the permanent home. ${ }^{50}$ Where a person has only stale or tenuous connections to the country of birth, the revival rule produces artificial results. ${ }^{51}$ Indeed, the revival rule may lead to a person being domiciled in a country where that person has never been. The consultation document leading to the 1987 report gives the following example: ${ }^{52}$

A is bom in India to English domiciled parents, and thus receives at birth a domicile in England. He remains in India after reaching the age of 16 and acquires a domicile of choice there. Later, in middle life, he leaves India intending to settle in the USA. At that point, A's domicile of choice in India ceases and his English domicile revives, although he has never even visited, let alone lived in, England. If A dies intestate before acquiring a domicile in one of the States of the Union, the succession to his moveable estate would be governed by English law.

The more appropriate result, of A dying domiciled in India, would be reached by the continuance rule under which a domicile of choice persists until a new domicile of choice has been established.

Some authors point out, however, that the continuance rule "sometimes produces equally bizarre results", 53 as indeed the consultation document for the 1987 report acknowledged: $:^{54}$

Take, for example, $\mathrm{C}$ born to parents resident and domiciled in Scotland where he also remains until he is an adult. Thereafter he moves to Ruritania where he sets up business and decides to make his permanent home. A revolution and change of government followed by political unrest and a threat of persecution drive him out and he moves to

$50 \mathrm{M}$ North and J J Fawcett, Cheshire and North's Private Intermational Law, $13^{\text {th }}$ edn (1999) 153.

51 See L Collins (ed), Dicey and Morris on the Conflict of Laws, $13^{\text {th }}$ edn (2000) para 6-077, example 5.

52 Law Commission and Scottish Law Commission, Private International Law: The Law of Domicile (Law Com WP No 88, Scot Law Com CM No 63, 1985) para 5.18, example (1). Further examples are given by North \& Fawcett, Private International Law 152-153.

53 J H C Morris, The Conflict of Latws, $6^{\text {th }}$ edn, by D McClean and $K$ Beevers (2005) para 2-029. Likewise J G Collier, Conflict of Laws, $3^{\text {rl }}$ edn (2001) 52. Both textbooks take Re Jones' Estate (1921) 192 Iowa 78; 182 NW 227 as an example: Mr Jones, a Welshman, moved to Iowa at the age of 33 to live there permanently but decided at the age of 65 to see out his final days in Wales. He died on the voyage to Wales. Applying the continuance rule it was held that $\mathrm{Mr}$ Jones had died domiciled in Iowa.

54 Law Commission and Scottish Law Commission, Private International Law: The Lat of Domicile (Law Com WP No 88, Scot Law Com CM No 63, 1985) para 5.19. 
the USA where he has business interests. However, by this time, $\mathrm{C}$ has resolved never to return to Ruritania, but to retire to Scotland when he stops work. He then dies. According to the continuance rule his domicile on death would be Ruritania, the one country in the world in which he has positively resolved never again to live, whereas the revival rule would have given him a domicile in Scotland.

But even though the continuance rule may produce artificial results on rare occasions, this rule is still preferable to the revival rule, for the following reasons. ${ }^{5.5}$ First, the continuance rule ensures that a person is domiciled in a country in which that person has at one time lived whereas the revival rule can lead to a person being domiciled in a country where that person has never lived. Secondly, by providing that a domicile can only be lost through the acquisition of a new domicile, the continuance rule renders obsolete all rules on the abandonment of a domicile which are the companion of the revival rule. Finally, since countries such as Australia, ${ }^{56}$ New Zealand ${ }^{57}$ and the United States ${ }^{58}$ have adopted the continuance rule, the United Kingdom should follow suit. It may be argued that the revival rule should not be abandoned in Scots law alone, in the interests of uniformity within the United Kingdom. But this uniformity has been lost in any event, as section 22 parts English and Scots law at least in determining the domicile of people between birth and their sixteenth birthday.

\section{TRANSITIONAL PROVISION}

The 2006 Act came into force on 4 May 2006, and article 4 of the commencement Order $^{59}$ provides that section 22 of the $\Lambda$ ct "shall not apply in relation to any proceedings which commenced before 4th May 2006". Interestingly, however, the Order does not provide that section 22 governs the domicile of people for the time, and only for the time, after the coming into force of the Act. The implications seem worth exploring.

In proceedings which commenced before 4 May 2006 the old domicile rules still apply even in the (theoretical) case that the domicile of a person has to be

55 Law Commissions, Report on Domicile para 5.24.

56 Domicile Act 1982 (Commonwealth) s 7: "The rule of law whereby the domicile of origin revives upon the abandonment of a domicile of choice without the acquisition of a new domicile of choice is abolished and the domicile a person has at any time continues until he acquires a different domicile."

57 Domicile Act 1976 s 11: "A new domicile acquired in accordance with section 9 of this Act continues until a further new domicile is acquired in accordance with that section; and the rule of law known as the revival of domicile of origin whereby a person's domicile of origin revives upon his abandoning a domicile of choice is hereby abolished."

58 The leading example is Re Jones' Estate (1921) 192 Iowa 78; 182 NW 227. See also Re Moore's Estate (1966) 68 Wash.2d 792 at 796; 415 P.2d 653 at 656; Restatement (Second) of Conflict of Laws (1971) $\$$ 19: "A domicile once established continues until it is superseded by a new domicile."

59 Family Law (Scotland) Act 2006 (Commencement, Transitional Provisions and Savings) Order 2006, SSI $2006 / 212$. 
determined for a time on or after that date. Conversely, in proceedings which commenced on or after 4 May 2006 the rules of section 22 apply even, it seems, for the purpose of determining the domicile of a person before 4 May 2006. This retrospective effect would be particularly significant if, contrary to the suggestion above, the revival rule were to survive. Thus if a person's domicile of origin were able to revive in the person's adult life, the revived domicile of origin would have to be determined (in proceedings which commenced on or after 4 May 2006) by ascertaining with which country the person was most closely connected at the time of birth, no matter how long ago that was. The domicile of origin of people born before 4 May 2006 could thus change for several decades back. This long-reaching change would be largely avoided if the revival rule were abandoned as of 4 May 2006 , for without the revival rule the domicile at birth is hardly ever relevant.

\section{E. CONCLUSION}

The introduction of a test of closest connection for determining the domicile of children by section 22 of the Family Law (Scotland) Act 2006 was an overdue step towards the equal treatment of all children regardless of the marital status of their parents. In this respect, Scots law has taken the lead in implementing a recommendation made jointly by the Law Commission for England and Wales and the Scottish Law Commission. English law should now follow suit.

In order to create certainty for a large group of cases, section $22(1)$ and (2) provides that where both parents are domiciled in the same country and the child has a home with at least one of them, the child shares the parents' domicile whether or not the test of closest connection would come to the same result. This inflexible rule may be defended on the ground that the parents' domicile will usually be the country of closest connection anyway, and where it is not, a unity of domicile for the whole family has its own advantages.

According to the explanatory notes to the Act, the new test of closest connection also governs a person's domicile of origin. But to apply section 22 to the domicile of origin sits unhappily with the fact that this provision defines the domicile only for "persons under 16 ", assuming it is maintained that the domicile of origin may revive in a person's adult life in order to fill a gap between two domiciles of choice. Since the revival rule may lead to a person being domiciled in a country in which that person has never been, the courts should adopt the continuance rule according to which a domicile of choice persists until a new domicile is established. Such a development of the law would be supported by policy arguments, would render the wording of section 22 wholly accurate, and would largely avoid the retrospective change of the domicile of origin of people born before the Act came into force. 